\title{
Phytochemical evaluation and investigations in to sedative properties of Datura stramonium (Linn) seeds in experimental mice
}

\author{
Malami $I^{1}$, Halilu, M.E ${ }^{1}$, Mathias, $S^{1}$, Alhassan M.A ${ }^{2}$ \\ ${ }^{I}$ (Department of Pharmacognosy and Ethnopharmacy, Usmanu DanfodiyoUniversity, Sokoto, Nigeria) \\ ${ }_{2}^{2}$ (Department of Pharmaceutical and Medicinal Chemistry, Usmanu DanfodiyoUniversity, Sokoto, Nigeria)
}

\begin{abstract}
Datura stramonium $\mathrm{L}$ is used as a sedative for the management of insomnia, and the seeds have long been used as drug of abuse by the young people for hallucination purpose. The present study was designed to investigate the sedative properties of seeds extract of D. stramonium using animal model. Diazepam-induced sleeping time test was used in this investigation. Phytochemical screening of the aqueous seed extract shows the presence of Tannins, cardiac glycosides, anthraquinones, saponins, triterpenes, flavonoids as well as alkaloids. The seeds extract of $D$. stramonium significantly $(p<0.01)$ increased the duration of sleep induced by diazepam at a dose of 40 and $80 \mathrm{mg} / \mathrm{kg} \mathrm{b}$.wt. In conclusion, the results of our current investigations revealed that D. stramonium may possess sedative properties which support the use of the seeds extract for the management of insomnia.
\end{abstract}

Keywords: Datura stramonium, diazepam, GABA $A_{A}$ receptors, insomnia, phytochemical evaluation,

\section{Introduction}

Insomnia is a widespread health complaint and the most common sleep disorders that affect people of all ages around the world [1,2]. About $10-15 \%$ of adult population suffers from chronic insomnia, and additional $25-35 \%$ has transient or occasional insomnia [3]. The most widely used drugs in the management of insomnia are benzodiazepines such as diazepam. The use of benzodiazepines in the management of insomnia is associated with well known problems such as 'hangover' effects, dependence, addiction, withdrawal symptoms and subsequent drug resistance [4].

Datura stramonium L. (family solanaceae) is an annual herb which forms a bush and grows from 1 to $1.5 \mathrm{~m}$ in height. It is commonly known as jimsonweed, thorn apple, angel's trumpet and devil's trumpet [5] and however, it is commonly known as babajiji in part of Northern Nigerian. It grows wild in most tropical countries including Nigeria, Bangladesh, India, and South America. D. stramonium is used as a mydriatic agent, as a sedative for the management of insomnia, an anodyne [6] and the seeds have long been used as drug of abuse by the young people for hallucination purpose. It contains toxic anticholinergic alkaloids atropine, scopolamine and hyosciamine [7]. Atropine and scopolamine are competitive antagonists of muscarinic cholinergic receptors and are central nervous system depressants [8]. All parts of the plant are toxic, but the highest amount of the alkaloids is contained in ripe seeds $[9,10]$.

Despite the frequent uses of $D$. stramonium for the management of insomnia, there are currently no scientific reports on sedative properties $D$. stramonium. However, this study was aimed to investigate sedative properties of seeds extract of $D$. stramonium using animal model.

\subsection{Plant material, animals, and drugs}

\section{Materials And Method}

The plant material was collected around the bushes at the eastern bypass in Sokoto, on $20^{\text {th }}$ Oct, 2012. The plant was taxonomically identified at the herbarium section of the Biological Science Department, Usmanu Danfodiyo University, Sokoto and kept for referencing.

Adult Swiss albino mice of both sexes weighing 21-30g were obtained from Department of Pharmacology and Toxicology, Faculty of Pharmaceutical sciences, Usmanu Danfodiyo University and were kept at the animal house under controlled environment at $22 \pm 2^{\circ} \mathrm{C}$. The animals were allowed to acclimatize under standard feeds and water access for a period of 2 weeks before the commencement of the experiment under which twelve hours light and twelve hours dark cycle was ensured. All procedure followed were in accordance with the ethical standard of the European Union Guidelines for Animals Experimentation and approved by the Institutional Animal Care Committee.

The seeds extract of Datura stramonium was prepared by simple maceration technique in aqueous for $48 \mathrm{~h}$ and concentrated by evaporation at reduced temperature. The solid extract obtained was dissolved in distilled water for pharmacological studies. Diazepam was supplied from BDH Ltd, Poole, England. 


\subsection{Phytochemical screening}

The various chemical constituents of the seeds extract were carried out in accordance with the standard protocol as described Trease and Evans [11].

\subsection{Diazepam-Induced Sleeping Time test}

A method described by Beretz [12] and modified by Rakotonirina [13] was adopted to evaluate sleep potentiating effect of the seeds extract. The animals were randomly divided in to four groups of five animals each $(n=5)$. All the animals received the drug by intraperitonial injection. One control group received normal saline $(1 \mathrm{~m} / \mathrm{kg}$ b.wt). Three groups received test extract $(20,40$ and $80 \mathrm{mg} / \mathrm{kg}$ b.wt) respectively. All animals were administered diazepam ( $3 \mathrm{mg} / \mathrm{kg}$, b.wt) $30 \mathrm{~min}$ after administration of normal saline or the test extract. The time between the loss of the straightening reflex and the regain of this reflex was measured as the sleeping time.

\subsection{Statistical analysis}

The results were expressed as means \pm SD using one-way ANOVA followed by Dunnett's test for multiple comparisons.

\section{Result and discussion}

Phytochemical screening of aqueous seed extract of Datura stramonium shows the presence of Tannins, cardiac glycosides, anthraquinones, saponins, triterpenes, flavonoids and alkaloids. The seeds extract of $D$. stramonium at a dose of $20 \mathrm{mg} / \mathrm{kg}$ showed no significant $(\mathrm{p}>0.01)$ different from the normal control. However, at a dose of 40 and $80 \mathrm{mg}$ significantly $(\mathrm{p}<0.01)$ potentiated by increasing the duration of sleep induced by diazepam in a dose-dependent manner (Fig. 1).

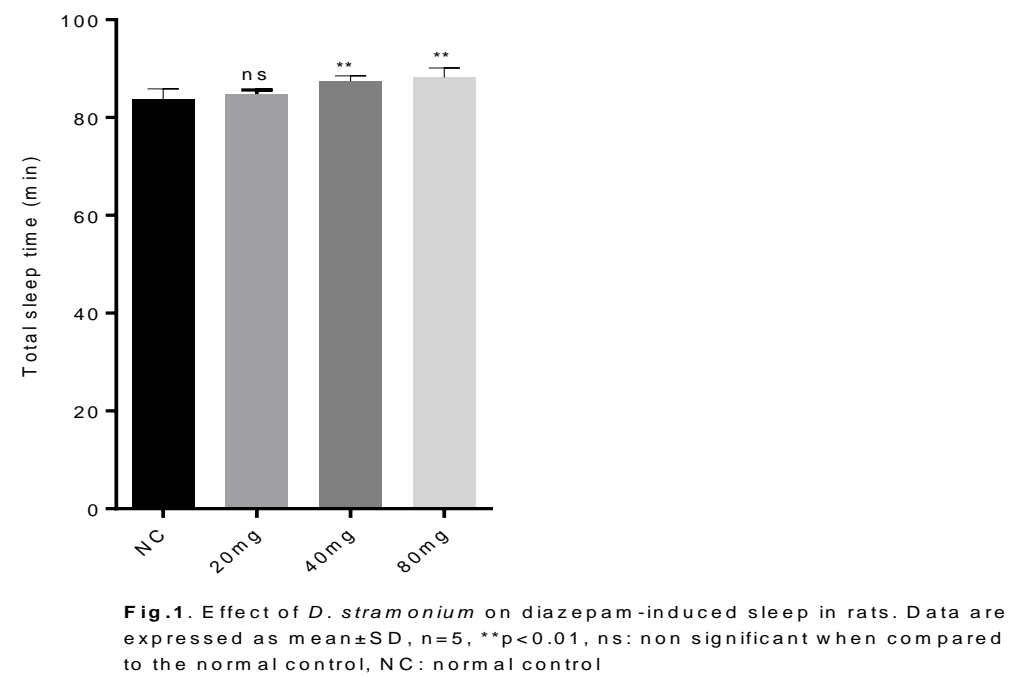

Diazepam-induced sleeping time test model is considered to be a valid animal model to test for sedative effects of drugs. Potentiation of diazepam-induced sleep by plant extracts suggests that they possess sedative property [14]. However, our current findings showed that D. stramonium increased the duration of sleep induced by diazepam at the dose of 20,40 and $80 \mathrm{mg} / \mathrm{kg}$. The sedative effects might suggest that D. stramonium may possibly act by interacting with $\mathrm{GABA}_{\mathrm{A}}$ receptor via their benzodiazepines-binding site. GABA $(\gamma$-amino butyric acid) systems are known to play an important role in sleep and positive allosteric modulators of $\mathrm{GABA}_{\mathrm{A}}$ receptor (e.g. benzodiazepines) are widely used to promote restful sleep [15]. Studies have shown that flavonoids present in the plant are able to modulate $\mathrm{GABA}_{\mathrm{A}}$ receptors [16]. Therefore, it's north worthy to suggest that flavonoids detected in the plant extract may be responsible for the pharmacological effects observed in this investigation.

\section{Conclusion}

In conclusion, the result of our present investigations shown Datura stramonium possessed sedative properties which support the use of the seeds extract in traditional medicine for the management of insomnia. However, we may suggest that the sedative properties of $D$. stramonium may be due to the presence of flavonoids detected in the seeds extract which exert their effect on $\mathrm{GABA}_{\mathrm{A}}$ receptors. 


\section{References}

[1] S. Choa , M. Shimizub , J. Leec, D. Hana, C. Junga , J. Jo, and Y. Kima. Hypnotic effects and binding studies for GABA $A_{A}$ and 5HT2C receptors of traditional medicinal plants used in Asia for insomnia. Journal of Ethnopharmacology. In press

[2] S. L. Guzmán, J. L. Balderas, A. Aguilar and A. Navarrete. Sedative activity of some plants used in Mexico to treat insomnia. Rev. Latinoamer. Quím, 37(3), 2009, 243-251

[3] K. Doghramji. The epidemiology and diagnosis of insomnia. American Journal of Managed Care, 12, 2006, 214-220.

[4] P. Tyrer. Risk of dependence onbenzodiazepine drugs. The importance of patientselection. British Medical Journal, 298, 1989, 102105

[5] M.B.Forrester. Jimson weeds (Datura stramonium) exposures in Texas, 1998-2004. J. Toxicol. Envir. Health, 69, 2006, 1757-1762

[6] A. Gani. Introduction to Pharmacognosy. (Ahmadu Bello University Press Ltd. 1990)

[7] N. Mahdeb, A. Bouzidi, N. Kara, Z. Benouadah, S. Soufane. Acute and subacute toxicity studies of alkaloids of seeds and synthetic alkaloids of Datura stramonium in female rats. Pharmacologia. 3(11), 2012, 598-604

[8] J.H. Halpern. Hallucinogens and dissociative agents naturally growing in the United States. J. Pharmacol. Therap., 102, 2004, $131-138$

[9] E. Miraldi, A. Masti, S. Ferri, I. Comparini. Distribution of hyoscyamine and scopolamine in Datura stramonium. Fitoterap., 72, 2001, 644-648.

[10] M. Friedman, C.E. Levin. Composition of Jimson Weed (Datura stramonium) Seeds. J. Agric. Food Chem., 37, 1989, 998-1005.

[11] G.ETrease, M.C. Evans. Textbook of Pharmacognosy. (14 ed. Balliere Tindall, London, 2002)

[12] A. Beretz, M. Haag-Berrurie, and R. Anton. Choix de méthodes pharmacologiques pour l'étude es activités de l'aubépine. Plantes médicinales et phytothérapie 4, 1978, 305-314.

[13] S. Rakotonirina, E. Ngo-Bum, A. Rakotonirina, M. Bopelet. Sedative properties of the decoction of the rhizome of Cyperus articulatus. Fitoterapia, 72, 2001, 22-29.

[14] M.G Magaji, A.H Yaro, A. Ahmed, M.I. Yakubu, J.A. Anuka. sedative activities of fractions obtained from methanolic root bark extract of Securinega virosa in mice. Nig. Journ. Pharm. Sci., 6(2), 2007, 28-33

[15] C. Gottesmann. GABA Mechanism and sleep. Neuroscience, 111, 2002, 231-239

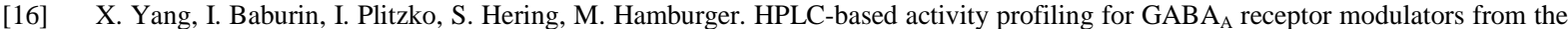
traditional Chinese herbal drug Kushen (Sophora flavescens root). Mol. Divers., 15(2), 2011, 361-372. 